\title{
RESOR KLAYAR DENGAN PENDEKATAN FENOMENOLOGI ARSITEKTUR DI KAWASAN WISATA PANTAI KLAYAR PACITAN
}

\author{
Stefany Windira Pramudita, Titis Srimuda Pitana, Sri Yuliani \\ Program Studi Arsitektur \\ Fakultas Teknik \\ Universitas Sebelas Maret Surakarta \\ Email : stefanywindira@gmail.com
}

\begin{abstract}
The background in designing Klayar Resort in Pacitan is based on the natural and cultural potential and the existed issue of cultural shift. The phenomenology architecture study is applied to grasp the phenomena where the architect acts as the instrument. The design goal is to represent a recreation place in creating a temporary living space, within the phenomenology comprehension of the physical and non-physical identification, where the place is capable of resurrecting the spirit of place with the identity that has already been formed. It is expected that the tourists can make a selforientation and self-identification with the surrounding by understanding the actual phenomena. The design issues that will be completed covers the determination of society and tourists' activities, the need and circulation space, the selection and processing of the site, the determination of design for each building in accordance with the phenomenology study. The obtained result will be a shelter in a form of a resort that is able to provide needs, both for the local society and the tourists, which is based on the existing phenomena, so that it will be able to represent the environment of the tourism area of Klayar beach.
\end{abstract}

Keywords: Culture, Phenomenology Architecture, Tourism Area, Resort.

\section{PENDAHULUAN}

Dalam perkembangan pariwisata di Indonesia, Pantai Klayar di Pacitan merupakan salah satu kawasan wisata unggulan yang mulai menarik perhatian para wisatawan baik domestik maupun mancanegara. Fenomena alam yang tersajikan berupa hamparan pantai pasir putih, jajaran batu karang, serta keberadaan seruling samudera menjadi daya tarik tersendiri dari Pantai Klayar ini. Selain fenomena alam terdapat pula fenomena budaya yang dihadirkan secara langsung dalam keseharian masyarakat setempat berupa kegiatan sehari-hari seperti bertani, berternak, nderes kelapa, dan berlayar. Keberadaan budaya lainnya dapat dilihat dari rumah-rumah joglo yang mereka tinggali. Fenomena budaya ini merupakan kualitas kehidupan masyarakat yang berindentitas.

Meningkatnya kunjungan wisatawan dari tahun ke tahun tentunya membawa dampak yang cukup besar dalam perkembangan kawasan wisata Pantai
Klayar dan sekitarnya. Isu-isu pergeseran budaya pun mulai bermunculan. Masyarakat yang awalnya memiliki mata pencaharian bergantung pada alam, sekarang mulai mengandalkan kedatangan para wisatawan. Masyarakat setempat ini menyediakan akomodasi berupa kondotel dan homestay dengan tarif permalam. Rumah joglo bermaterialkan kayu-kayu jati yang sebelumnya mereka tinggali dibongkar lalu diubah menjadi rumah bergaya modern bermaterialkan beton. Selain itu, di bibir pantai, masyarakat yang awalnya bekerja sebagai nelayan mulai beralih menjadi penjaja makanan instan dan menyewakan kamar mandi.

Studi fenomenologi arsitektur mencoba dimunculkan dalam perancangan Resor Klayar. Fenomenologi sendiri merupakan sebuah pendekatan filsafat yang berpusat pada analisis terhadap gejala yang menampakkan diri pada kesaran manusia (Bagus, 1996). Fenomenologi berkembang sebagai metode untuk pembelajaran ilmu yang 
membutuhkan data secara empiris, salah satunya adalah ilmu arsitektur. Metode fenomenologi sering digunakan oleh beberapa orang arsitek untuk memahami objek karya arsitektur lebih mendalam dengan cara mengalami. Seperti yang dijelaskan oleh salah satu arsitek Christian Norberg Schulz dalam kajian genius locinya, bahwa hubungan manusia dengan tempat (place) merupakan sebuah hubungan identifikasi yang cukup mendalam. Proses identifikasi manusia terhadap sebuah tempat adalah karakter, yang merupakan atribut yang membedakan satu tempat dengan lainnya sebagai kehadiran unik setiap tempat. Norberg Schulz mengistilahkan suatu tempat yang memiliki suatu karakter tersendiri dengan istilah genius loci atau roh dari tempat tertentu. Dalam kajian genius loci ini Norberg Schulz mulai memperkenalkan metode fenomenologi dalam upaya pencariannya mendapatkan pengertian konkret dari lingkungan (Ong, 2008:6). Oleh karena itu untuk mendapatkan fenomena-fenomena tersebut dibutuhkan pengalaman aktual dan keterlibatan langsung seorang arsitek. Dapat dikatakan arsitek menjadi instrumen dalam proses penangkapan fenomena. Fenomena yang tertangkap ini kemudian menjadi pertimbangan dalam perancangan resor.

Resor Klayar merupakan ruang tinggal sementara yang diharapkan mampu menumbuhkan kembali potensipotensi budaya setempat berdampingan dengan alam dengan pemahaman fenomenologi dalam segi fisik maupun non-fisik (suasana). Suasana yang dihadirkan mampu mengiring wisatawan untuk meruang dengan mengorientasikan diri dan mengidentifikasi diri dengan lingkungan sekitar dengan pemahaman fenomena aktual.

\section{METODE}

Metode yang digunakan dalam proses perancangan Resor Klayar dimulai dari studi lapangan dengan Metode Grounded Research digunakan sebagai metode kualitatif pengumpulan data karena penelitian yang dilakukan lebih fokus pada pencarian makna.

Penelitian menggunakan metode pengumpulan data grounded research dilakukan secara intensif berbaur dengan masyarakat di kawasan Pantai Klayar. Dengan bertempat tinggal sementara di salah satu rumah penduduk untuk mengamati keseharian yang terjadi demi mendapatkan fenomena-fenomena yang nampak untuk dijadikan sebagai data pertimbangan dalam desain Resor Klayar.

Data baik fisik maupun non-fisik yang didapat kemudian dianalisis lalu diterapkan ke dalam desain Resor Klayar.

\section{ANALISIS}

\section{A. Analisis Peruangan}

1. Tujuan: memperoleh jenis kebutuhan ruang.

2. Pertimbangan: pengelompokan kegiatan dan pelaku kegiatan.

3. Hasil analisis: pelaku kegiatan pada Resor Klayar adalah:
a. Pengunjung
b. Masyarakat setempat
c. Seniman
d. Paguyuban masyarakat

Kebutuhan ruang pada Resor Klayar ditentukan oleh kegiatan pelaku. Sebagian besar kegiatan yang terjadi merupakan kegiatan bersama. Berikut adalah kebutuhan ruang dan total luasan ruang yang dibutuhkan:

a. Kegiatan pengunjung: hunian resor, wedangan, kamar mandi umum, ruang pentas, masjid, pawon gedelalit.

Total luasasn: $2349,65 \mathrm{~m}^{2}$

b. Kegiatan masyarakat setempat: pawon gede/alit, kamar mandi umum, lumbung, wedangan, perpustakaan, masjid. Total luasan: 106,2 $\mathrm{m}^{2}$

c. Kegiatan seniman: balai seni, ruang pentas, wedangan, pawon, kamar mandi umum, masjid.

Total luasan: $45,8 \mathrm{~m}^{2}$

d. Kegiatan paguyuban masyarakat: area pengelolaan, wedangan, kamar mandi 
umum, pawon gedelalit, area servis.

Total luasan: $116,1 \mathrm{~m}^{2}$

Dari analisis di atas maka didapatkan pola hubung ruang sesuai dengan hubungan kegiatan yang terjadi. Alur sirkulasi yang terjadi sesuai dengan urutan kegiatan yang akan dilaksanakan di kawasan Resor Klayar (lihat Gambar 1).

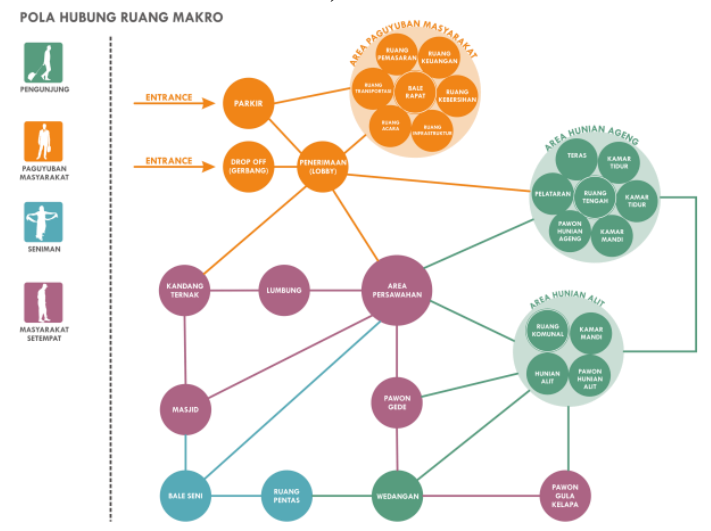

Gambar 1. Pola Hubungan Ruang Kawasan Resor Klayar.

B. Analisis Pemilihan Lokasi

1. Tujuan: memperoleh lokasi yang sesuai untuk mendukung keberadaan resor yang menggunakan pendekatan fenomenologi.

2. Pertimbangan: lahan luas, kawasan asri, dekat dengan pemukiman masyarakat, mudah diakses, tidak menyita ruang publik kawasan wisata Pantai Klayar, tapak yang terpilih memiliki potensi untuk merepresentasikan suasana kehidupan di Kawasan Wisata Pantai Klayar.

3. Hasil analisis: tapak terpilih berada di kawasan hutan dan pertanian warga dengan akses berupa jalan utama di sebelah barat kawasan. Kondisi tapak berkontur dengan interval $50 \mathrm{~cm}$. Di dalam tapak terdapat area persawahan yang tidak akan diolah namun nantinya akan menjadi pendukung kegiatan resor.

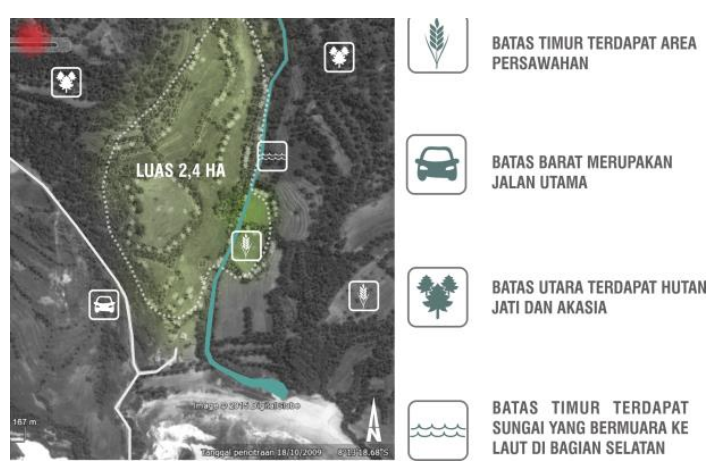

Gambar 2. Batas-Batas Lokasi Terpilih.

C. Analisis Pencapaian

1. Tujuan: menentukan letak main entrance dan side entrance.

2. Pertimbangan: kondisi dan potensi jalan di sekitar area tapak, sirkulasi yang jelas dan mudah dicapai, keamanan dan kenyamanan sirkulasi tanpa crossing antar pengguna.

3. Hasil analisis: akses menuju Resor Klayar hanya mampu dijangkau oleh pejalan kaki melalui jalan utama kemudian mengarah menuju gerbang yang berupa jalan setapak. Selebihnya untuk kendaraan bermotor sudah disediakan area parkir di seberang entrance.

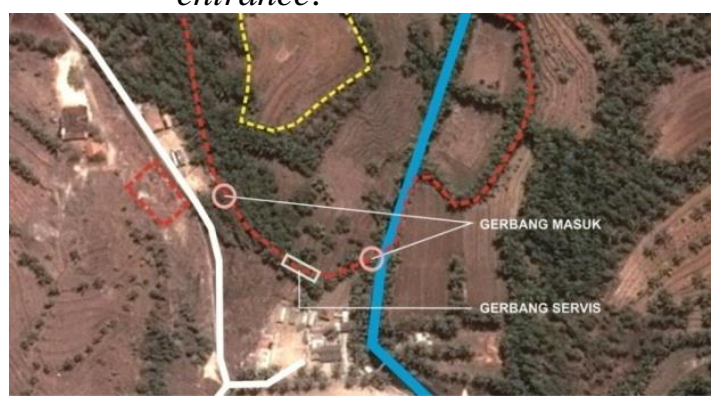

Gambar 3. Entrance Pada Tapak.

D. Analisis Sirkulasi dan Lansekap

Resor Klayar

1. Tujuan: memperoleh tata lansekap yang dihadirkan secara jujur dengan mempertahankan kondisi tapak yang sudah terbangun.

2. Pertimbangan: sirkulasi memanfaatkan view di dalam tapak, seminimal mungkin menggunakan material perkerasan fabrikasi, kontur diperlakukan secara jujur dan wajar.

3. Hasil analisis: sirkulasi pada kawasan resport terbagi menjadi 


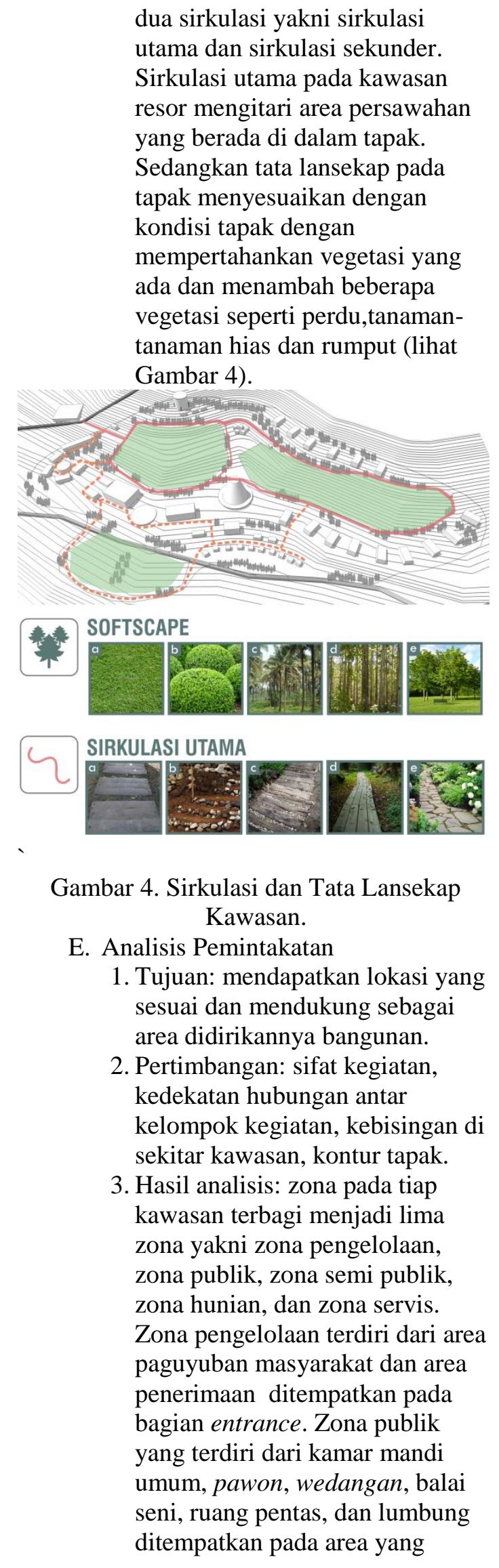

dua sirkulasi yakni sirkulasi

utama dan sirkulasi sekunder.

Sirkulasi utama pada kawasan

resor mengitari area persawahan

yang berada di dalam tapak.

gan

engan

ada dan menambah beberapa

vegetasi seperti perdu,tanamantanaman hias dan rumput (lihat Gambar 4)

SOFTSCAPE

SIRKULASI UTAMA

Gambar 4. Sirkulasi dan Tata Lansekap

Kawasan.

E. Analisis Pemintakatan

Tujuan: mendapatkan lokasi yang sesuai dan mendukung sebagai Peringan.

kedekatan hubungan antar kelompok kegiatan, kebisingan di tur tapak. kawasan terbagi menjadi lima zona yakni zona pengelolaan, zona publik, zona semi publik, zona hunian, dan zona servis. Zona pengelolaan terdiri dari area paguyuban masyarakat dan area penerimaan ditempatkan pada publik yang terdiri dari kamar mandi m, pawon, wedangan, bala ditempatkan pada area yang cukup bising yaitu di bagian selatan tapak. Zona semi publik terdiri dari masjid dan perpustakaan terletak di tengah kawasan. Zona hunian terletak pada area dengan kebisingan yang rendah yaitu di sebelah utara tapakmengitari area persawahan. Zona servis berupa tangki air berada pada kontur yang tertinggi yaitu pada bagian barat tapak (lihat Gambar 5).

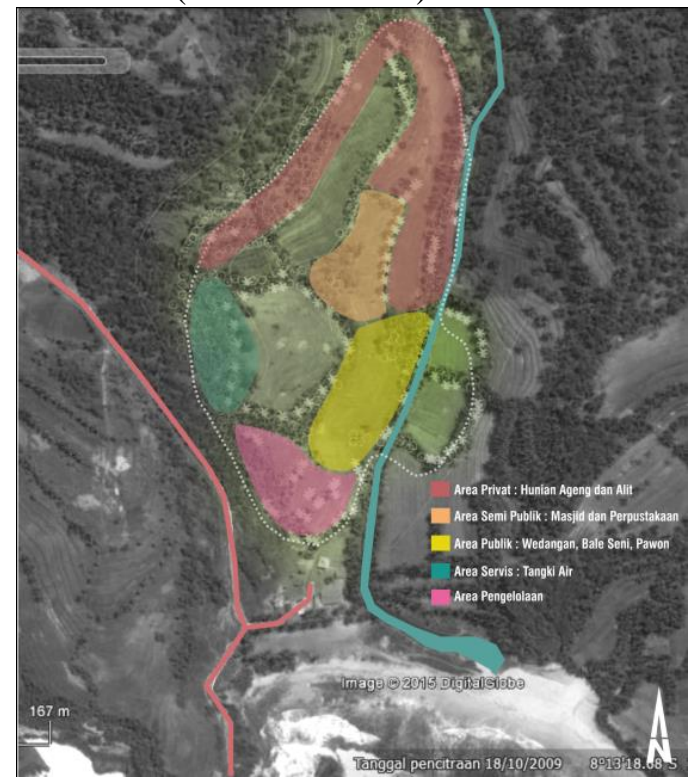

Gambar 5. Pemintakatan Pada Kawasan.

F. Analisis Gubahan Massa

1. Tujuan: menentukan gubahan massa yang sesuai dengan kebutuhan serta fenomena lingkungan setempat.

2. Pertimbangan: fleksibel, mengadopsi bentuk bangunan lokal, menyesuaikan ketinggian kontur.

3. Hasil analisis: gubahan massa menggunakan bentuk-bentuk dasar bangunan lokal di Kawasan Wisata Pantai Klayar kemudian disesuaikan dengan keadaan kontur yang ada di tapak. Tapak kawasan resor merupakan lahan berkontur dan terdapat area sawah di tengah tapak. Interval kontur 50 cm dengan jarak tiap kontur berkisar antara 3-5 m. Ketinggian kontur serta jarak tiap kontur mempengaruhi bentuk 
massa bangunan. Rumah panggung menjadi solusi terhadap tapak kontur guna menghindari adanya cut and fill dalam pengolahan tapak. Rumah panggung diterapkan pada massa bangunan yang berada pada tapak yang memiliki lebih dari satu kontur. Penerapan rumah panggung juga membantu sirkulasi angin pada kawasan (lihat Gambar 6).
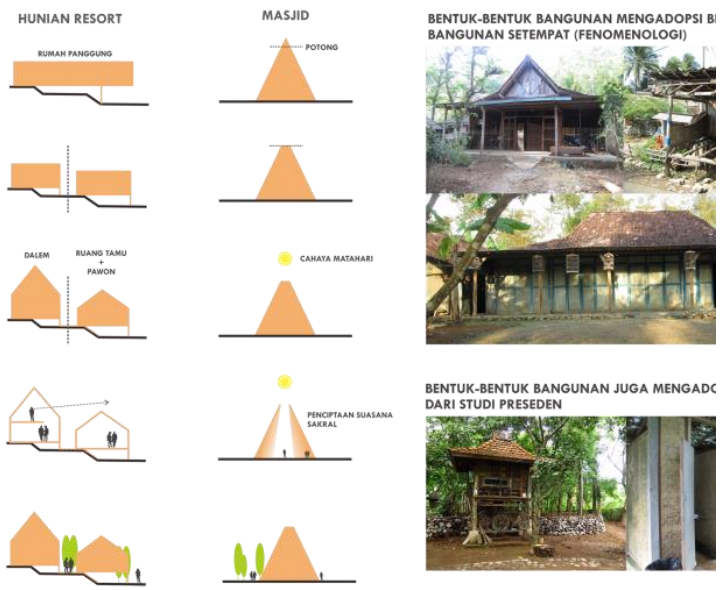

Gambar 6. Gubahan Massa Bangunan.

G. Analisis Bangunan

1. Tujuan: menentukan bangunan yang sesuai dengan studi Fenomenologi Arsitektur.

2. Pertimbangan: penggunaan material lokal, teknologi bahan sesuai dengan pemberdayaan material warga sekitar.

3. Hasil analisis: bangunan pada setiap massa bangunan resor menggunakan material-material lokal. Keberadaan struktur ditampilkan secara jujur dengan tujuan mendukung bangunan. Material-material yang tersedia di lingkungan kawasan Pantai Klayar dimanfaatkan dan diberlakukan secara jujur dan wajar layaknya rumah tinggal joglo yang masih berdiri saat ini.

Kebiasaan warga mengolah dan memberdayakan material lokal akan diaplikasikan pada setiap material bangunan di Resor Klayar, baik sebagai struktur maupun tampilan bangunan (lihat Gambar 7).

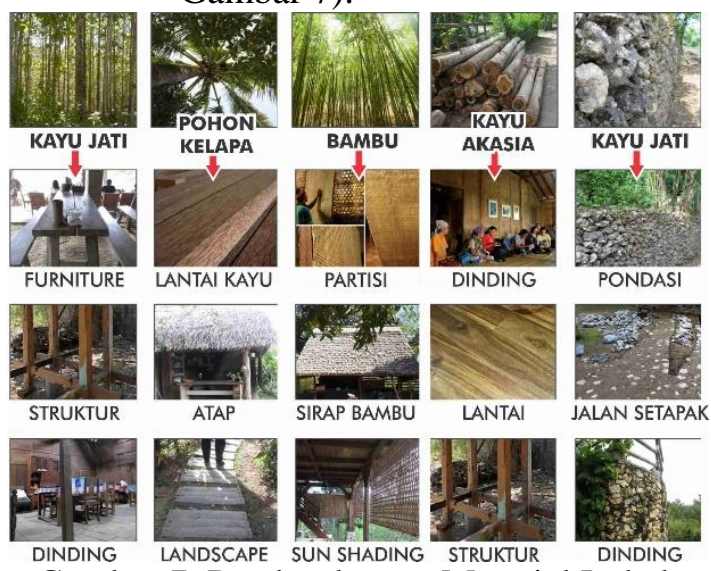

Gambar 7. Pemberdayaan Material Lokal.

H. Analisis Struktur Bangunan

1. Tujuan: menentukan struktur bangunan sesuai dengan kondisi tapak dan fenomena lingkungan.

2. Pertimbangan: material bangunan, kondisi tapak berkontur.

3. Hasil analisis: struktur bangunan menggunakan sistem bongkar pasang (knock down) untuk bangunan bermaterial kayu. Ada beberapa bangunan menggunakan struktur batu kali masif sekaligus digunakan sebagai dinding.

Pondasi yang digunakan menggunakan pondasi setempat atau umpak (lihat Gambar 8).

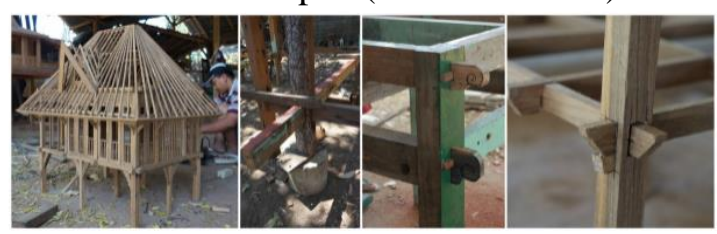

Gambar 8. Struktur Bangunan Resor.

I. Analisis Utilitas Kawasan

1. Tujuan: memperoleh sistem utilitas yang mampu memenuhi kebutuhan kawasan resor.

2. Pertimbangan: ketersediaan air, jaringan listrik desa.

3. Hasil analisis: sistem utilitas terdiri dari jaringan listrik dan jaringan air. Jaringan listrik kawasan resor menggunakan pasokan listrik PLN. Jaringan air terdiri dari jaringan air bersih dan air kotor (lihat Gambar 9). Jaringan air bersih didapat dari air tanah dan 
pengolahan air hujan atau dikenal dengan sebutan white water system (lihat Gambar 10). White water system merupakan sistem penampungan air hujan yang diolah hingga layak konsumsi. Jaringan air kotor berupa hasil buangan kamar mandi, dapur, serta limpahan air hujan dari selokan, diolah menggunakan grey water system. Air hasil olahan digunakan untuk menyiram tanaman dan mengairi persawahan (lihat Gambar 11).

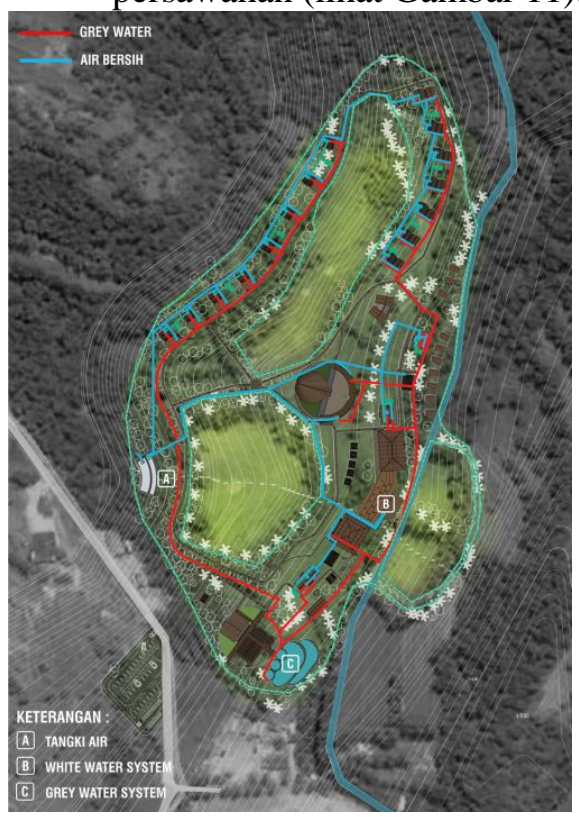

Gambar 9. Denah Jaringan Utilitas Air

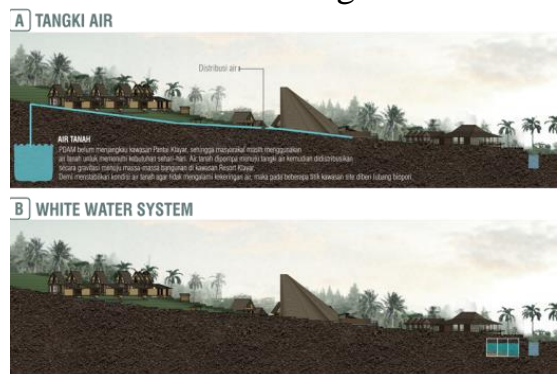

Gambar 10. Sistem Air Bersih.

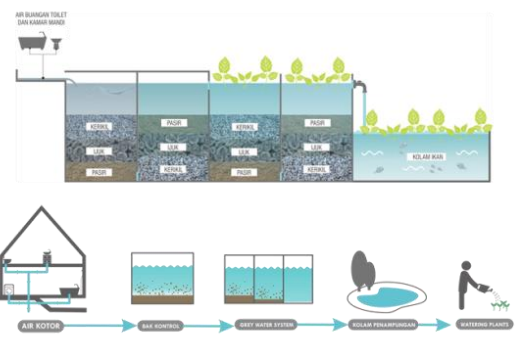

Gambar 11. Grey Water System.
IV. KESIMPULAN (KONSEP DESAIN)

Dari hasil analisis serta keterkaitan dari beberapa data diatas, maka diperoleh hasil berupa desain Resor Klayar di Pacitan sebagai berikut:

Nama : Resor Klayar

Lokasi : Kawasan Wisata Pantai

Luas Lahan $\quad: 24.000 \mathrm{~m}^{2}$

Luas Bangunan : 2617,75 $\mathrm{m}^{2}$

Daya Tampung : 300 orang

Pada Resor Klayar Fenomenologi Arsitektur dihadirkan pada penciptaan kawasan yang sesuai dengan fenomena budaya yang hadir di kawasan wisata Pantai Klayar. Seperti adanya interaksi antara wisatawan dan masyarakat di pawon dan wedangan (lihat Gambar 12 dan 13). Hunian ageng resor dibuat panggung dengan struktur dan interior yang didominasi kayu (lihat Gambar 14). Pintu gerbang Resor Klayar hanya mampu dilalui oleh pejalan kaki (lihat Gambar 15). Kamar mandi umum terdiri dari 4-6 bilik dengan tampilan bangunan menggunakan kayu dan tanaman rambat (lihat Gambar 16).

Kesenian budaya diwadahi pada bangunan Balai Seni dan setiap karya budaya ini akan dipentaskan pada ruang pentas yang dibuat terbuka dengan latar belakang pegunungan dan persawahan. Tribun penonton diberi peneduh pohon (lihat Gambar 17).

Terdapat ruang baca berupa perpustakaan kecil yang didesain semi terbuka dengan penanaman pohon di bagian tengah sebagai peneduh dan penyejuk (lihat Gambar 18).

Gubuk sawah terletak di beberapa titik kawasan. Di gubuk sawah ini masyarakat dan wisatawan bersamasama mengelola area persawahan (lihat Gambar 19).

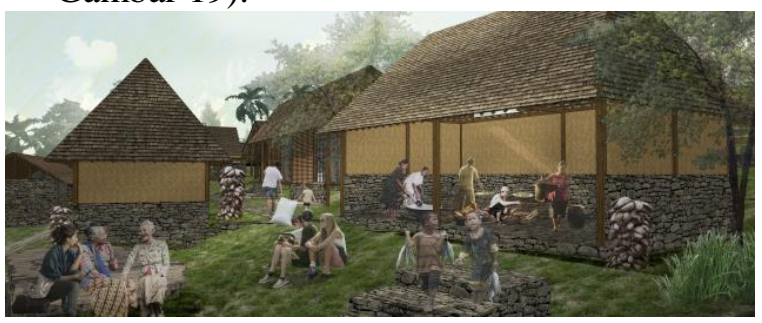

Gambar 12. Suasana Pawon. 


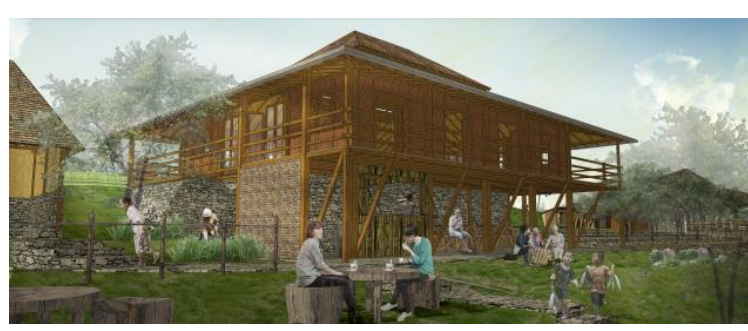

Gambar 13. Eksterior Wedangan.

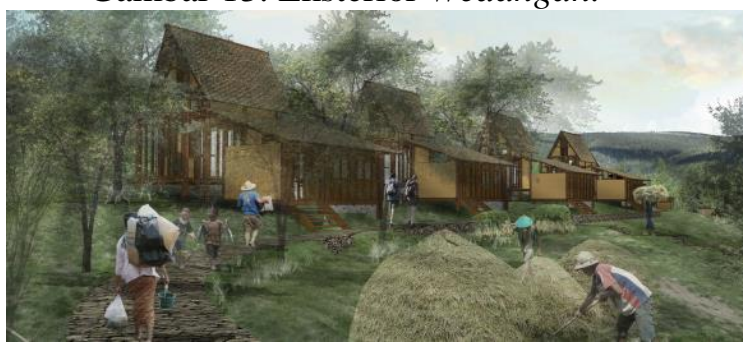

Gambar 14. Eksterior Kawasan Hunian Ageng.

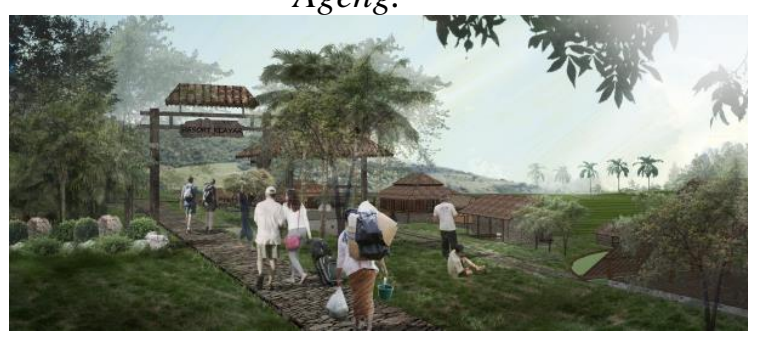

Gambar 15. Gerbang Resor Klayar.

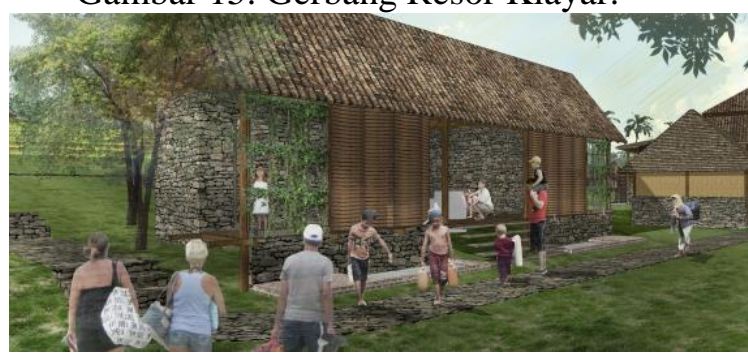

Gambar 16. Eksterior Kamar Mandi Umum.

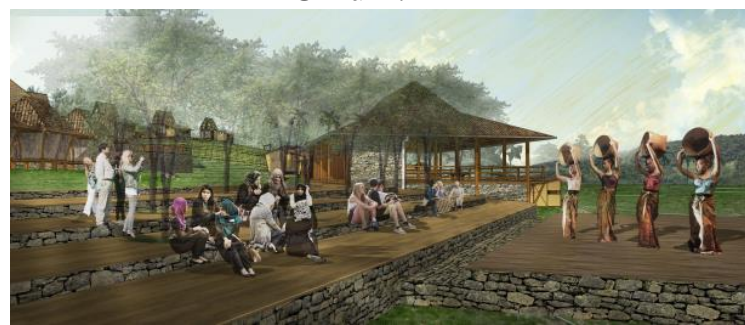

Gambar 17. Suasana Ruang Pentas dan Balai Seni.

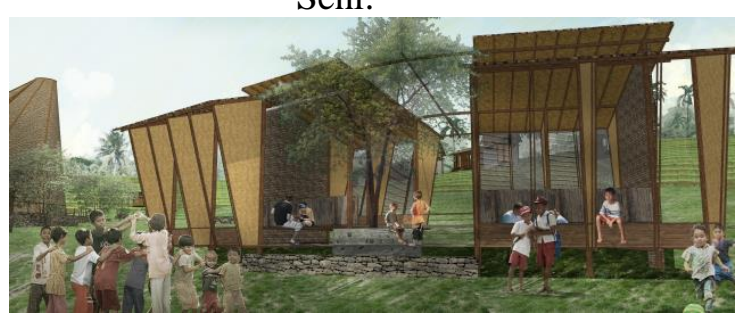

Gambar 18. Eksterior Perpustakaan.

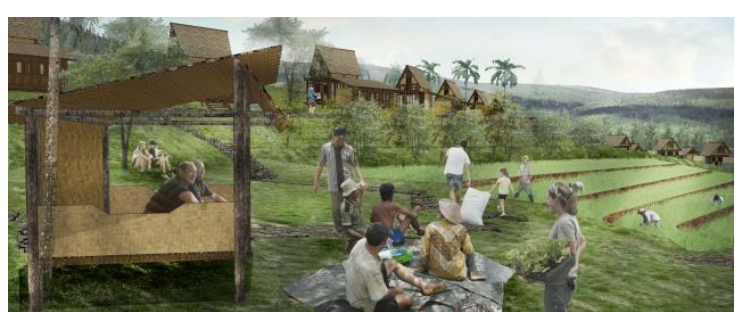

Gambar 19. Suasana Gubuk Sawah.

\section{REFERENSI}

Bagus, Lorens. 2002. Kamus Filsafat. Jakarta: PT Gramedia Pustaka Utama. Ong, H.I. 2008. "Kajian Genius Loci Dengan Fenomenologi Arsitektur Studi Kasus: Kawasan Kesawan”. Medan: Universitas Sumatera Utara. Tesis tidak dipublikasikan. 